\title{
Introduction by the Editor-in-Chief
}

National laws, regulations and case law concerning work and the workplace and for EU members, EU labor law - are of critical importance to labor lawyers and scholars. As international labor law becomes increasingly important, The Hague Institute for Global Justice and Leiden University have launched the Social Justice Expertise Center, now home to the International Labor Rights Case Law (ILaRC) Journal, published by BRILL |NIJHOFF.

The role of international treaties, conventions, declarations, accords and agreements concerning labor rights is growing in jurisprudence. Decades of work in this field has resulted in the international labor guidelines produced by the International Labor Organization (ILO) and the Council of Europe. Trade agreements between States and numerous codes of conduct on corporate social responsibility signed by corporations and industries have also added to this body of law. Overall, a huge variety of texts exist that are relevant to the practice of labor law, and rapid globalization means practitioners must be aware of developments so as to better advise their clients.

There is currently no international labor law journal which focuses specifically on the five core international labor standards: (1) The right to organize and bargain collectively; (2) The right to strike; (3) The prohibition of child labor and forced labor; (4) Anti-discrimination rules; and (5) International rules and regulations concerning health and safety at the workplace.

ILaRC endeavors to fill this niche by including the most recent cases and leading interpretations of international labor norms and regulations on these core standards. The cases will include, for instance, interpretation of ILO Conventions by various ILO Committees as well as international cases from international and national courts, such as the European Court of Human Rights and the InterAmerican Court of Human Rights, and from bodies such as the OECD.

Each issue will contain relevant extracts from decisions, and outline their relevance for international labor law practice, thus providing an invaluable addition to the toolbox of labor lawyers, corporate counsel and consultants from legal systems around the world.

\section{Professor Paul van der Heijden}

Leiden, The Netherlands

March 2015 